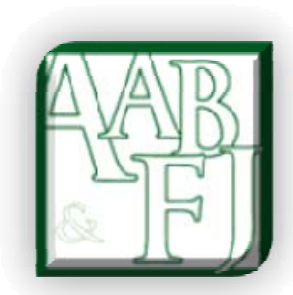

\title{
The Asian Development Model and Mining Reforms in Indonesia
}

\author{
John Passant ${ }^{1}$, John McLaren ${ }^{2}$, Parulian Silaen ${ }^{3}$ and Ananda Wickramasinghe ${ }^{4}$
}

\begin{abstract}
The aim of this paper is to provide accounting, marketing, management, finance and legal professionals who are engaged with emerging economies with an introduction to the 'Asian Development Model' and to use the mining reforms in Indonesia as an example of the Model in operation. This will assist those professionals in recognising the challenges faced by businesses in Australia and New Zealand when governments in South East Asian countries attempt to 'catch up' to the developed world and at the same time attempt to spread the benefits of the development to their people.

The paper argues that there is an Asian Development Model and that the Indonesian mining reforms, in particular the requirement over time for 51 percent Indonesian Government ownership and the ban on the export of unprocessed resources, represent an attempt by the Indonesian State to speed up industrialisation in their country and to spread more of the benefits from mining to ordinary citizens in the recently democratised and politically decentralised country. In attempting to show strength however, the Indonesian state is exposing some weakness. The impact on jobs, revenue and production has been adverse although Foreign Direct Investment has increased. This latter may be because it is foreign multinational mining companies who are better placed than local mining enterprises to build smelters. The success of developing mining might be at the expense of local capital. In other words state intervention does not always produce all of the desired outcomes. It is not a panacea.
\end{abstract}

JEL Classification: M48, B51, B24, N55

Keywords: Asian Development Model, Mining Reforms, Indonesia

\footnotetext{
${ }^{1}$ Australian National University, Australia.

2 James Cook University, Singapore. john.mclaren@jcu.edu.au

${ }^{3}$ University of Wollongong, Australia

${ }^{4}$ University of Wollongong, Australia
} 


\section{Introduction}

One major question in any discussion about business and the state in emerging economies relates to the Asian Development Model: is there such a concept? (Pomeranz, 2001) What is it? Is it unchanging? Does it work? Are there lessons for other emerging economies? This paper aims to give readers unfamiliar with the interaction between the State and capital in East Asia a general and easy to understand introduction to the concept of the Asian Development Model to help them in their appreciation of emerging economies. The paper then tests that model in the context of mining reforms in Indonesia.

Part II of the paper discusses the Asian Development Model, including some background, debates about the model and whether it is a new phenomenon or not, before summarising the key points. Part III then introduces the reader to the mining reforms in Indonesia: reforms which confirm that state intervention is a key component of the Model. Part IV concludes by arguing that the Asian Development Model is very much alive and, drawing on the mining reforms in Indonesia, shows the weakness of the State if it does not have a clear idea of its role as the dominant actor. ${ }^{5}$

\section{The Asian Development Model}

\section{A Background}

Based on the experience and economic success of Japan after the Second World War, and then South Korea, Taiwan, Hong Kong and Singapore, followed later by others like Thailand, Malaysia and Indonesia, rapid capitalist development in East Asia prompted debate about whether there was an Asian Development Model, one based on government intervention in the market in some form such as import substitution industrialisation. This was often followed by export orientation for the recently protected and built up industries, tariffs, promotion of local industry, currency manipulation, capital controls and the like. Most academics concluded there was such a Model. For example Hall (2003, p.73) reference Wade and Veneroso (1998) by saying,

The Asian development model had been based on high domestic household savings rates, and a number of practices featuring public-private sector cooperation, such as high corporate debt/equity ratios, bank-firm-state collaboration, national industrial strategies, and investment incentives conditional on international competitiveness.

That initial success in Japan after the Second World War and then stagnation from the 1990s until today, and the impact of the Asian Financial Crisis on the region from 1997 on, coupled with the shift to market based economies under Communist government political and economic control in China, produced further debate on the market-state relationship (Baek, Seung-Wook, 2005). The Global Financial Crisis and its impact on North America and much of Europe, but not to date on much of Asia, has also prompted a further re-visiting of the socalled economic miracles in Asia (World Bank,1993).

\footnotetext{
${ }^{5}$ The idea is to examine in another paper if there are also lessons from the Indonesian mining reform program for resource rich developed countries like Australia.
} 
In a nutshell some have interpreted these positive economic developments, in particular moving from peasant to industrial societies in much of Asia since the Second World War as highlighting the importance of government, of state guidance, of intervention and control, sometimes called beneficial strategic State interventions (Amsden, 1994) in moving a country from a backward economic State to a developing or developed capitalist one. Others emphasise the 1997 Asian Financial Crisis and pinpoint its causes as over regulation and too much state interference (IMF, 1997) or, echoing the idea of the state gone bad, corruption and cronyism (Freeman and Hew, 2002). Singh (2002) rebuts this IMF argument that the causes of the Asian Financial Crisis were too much regulation and state interference and concludes this is incorrect. He argues at that '... the current widely held and highly influential thesis that the root cause of the present financial crisis in South East and East Asian countries lies in the dirigiste ${ }^{6}$ model of Asian capitalism pursued by these countries is seriously mistaken. The analysis of the paper suggests that the fundamental reason for the crisis is to be found not in too much, but rather in too little government control over the financial liberalisation process which these countries implemented in the recent period' (Singh, 2002, p.339). Similar voices are sounding comparable warnings as China's growth slows today.

\section{B Debates about the Model}

There are a range of views on whether the Asian Development Model exists, and if it does, the nature of that model and, from the free market theorists, why it should not exist. These include Marxist and Neo-Marxist approaches, theories of Asiatic power and politics, and neoliberalism to name a few. It is not the place of this paper to go into these in any depth but rather to try to introduce readers to the general ideas.

The countries of East Asia have different histories, colonial experiences, political systems and governments, economies, populations, resources, public services, cultures and so on. They are also at different stages of development, often captured by reference to the First, Second and Third Wave of Asian Tigers. For these reasons and others Hal Hill argues that there is not yet a South East Asian Development Model among countries like Indonesia, Singapore, Myanmar, Malaysia, but that one may be developing as regional cooperation and integration into the global economy continue apace (Hill, 2014).

Perkins $(2013,201)$ makes the case that:

... no single model describes accurately what the 10 most successful economies in [East Asia] did to achieve this transformation. In most of the countries ... more than one model or approach to development was tried as conditions within as well as between the countries changed. There were common themes, however, and the countries that started the transformation later learned from those that went ahead.

However it is accepted here that the poor economic position of many of the countries of East Asia relative to the developed world after the Second World War and the process of de-

\footnotetext{
${ }^{6}$ Defined as State control of economic or financial matters.
} 
colonisation and globalisation has seen a set of similar responses develop over time that have enabled many of them to experience rapid and sustained growth, or begin that process, apart from the Asian Financial Crisis in 1997 and 1998 and the recovery years after that.

Overarching the similar responses is the fact of government intervention, with the state taking hands-on actions it perceives as being best able to deliver capitalist growth. This overarching theme of government action plus the broad similarity of the responses can be and has been called the Asian Development Model, among other things. As Freeman and Hew (2002, pp. 2-3) put it:

[A] very broad sketch of what constitutes the EADM [East Asia Development Model] particularly in Southeast Asia - can be identified, comprising a movement in 'the dynamic fulcrum of the economy towards industrial activity', with a strong emphasis on orienting the manufacturing sector towards mass production for export. In addition, a heavy reliance on FDI [foreign direct investment] from multinational companies as a major source of both capital and other non-financial inputs has tended to be an important element of the EADM, particularly in much of Southeast Asia. Cheap, yet relatively well-educated, and skilled labour has been a critical factor attracting foreign capital to establish labour-intensive operations in large parts of East Asia, although some countries have been quite successful in gradually moving parts of their industrial sector up the value-added chain.

Seung-Wook Baek echoes this. He says (Baek, 2005, p. 485):

Key elements of this shared development model include state control over finance, direct support for state owned enterprises by the government, import substitution, industrialisation in heavy industry, a high dependence on export markets and a high rate of domestic savings.

Robert Wade (2004) argues that there are two key elements to the Model. They are 'a politically empowered exercise of foresight and a bureaucratically empowered array of measures to promote the industries and technologies needed for the economy's future growth. John McKay explains these elements in more detail and shows the framework in or guiding principles under which the specific policies arising from Asian Development Model are developed and implemented (McKay, 2010). He also argues for its wider application to developing countries, including those in Africa.

For McKay the essence of the Model is having clear goals, strong leadership, effective bureaucratic systems, willing followers, a leading role for the state, close ties between business and government, seeing exports as the key to growth, state investment via high local savings, tight control of financial and banking systems, and transforming the entire society, with a promise of better times for future generations (McKay, 2010).

It is within this framework that the specific policies of each country aimed at modernising and developing the nation can be understood. Obviously Singapore with a small population and no natural resources is very different to Indonesia with a large population and a reserve of resources to satisfy some of the world's energy and other needs. Yet the overall framework 
for decision making and implementation of state-led policies appears very similar. In other words the goals and the mechanisms remain much the same. In the case of Singapore realpolitik and 'realeconomik' demands a society taking advantage of its physical location and becoming both an entrepot economy and a financial centre (Ariff and Khalid, 2000) and key second home for global multinationals like Google. In the case of Indonesia the reality of natural resources in global demand and a recently enfranchised but often poor people results in, for example, state measures to impose national development requirements like downstream processing and divestment to local owners on the major mining companies as a way of re-distributing wealth to the poor.

It would also be a mistake to see Indonesia and Singapore, to continue the example, as autocratic and completely separate States. Both are central to the Association of South-East Asian Nations (Guo, 2014). They trade, have cross border investment, and undertake military and security cooperation (Channel News Asia, 2014). Singapore for example is keen to both facilitate and further investment in Indonesia (Guo, 2014). They also trade extensively with other countries in the region.

While separate paths based on separate realities appear to differentiate the two, what also unites them is a State prepared to impose its will when needed on capital and the market. Even those globally integrated economies like Singapore had to make the transition to the global market and did so and continue to do so under the guidance of a strong State. Thus, as Yeoh and Yeung note (2010, p. 13):

The Singapore model of economic development is a variation of the 'development state model' economic restructuring, industrial transformation, and rapid economic growth are achieved through 'collaborations' with multinational enterprises (MNEs) rather than with local industrial enterprises.

Indonesia by contrast has a long term development plan segmented into five year blocs. These five year government plans began in 2005 and will run through to 2025, with each segment containing different but growth related goals (The World Bank). This is classic statism in which the state guides development, and this has relevance for the later discussion about the Indonesian government's proposals for the mining sector. 


\section{State control is not a new concept}

Industrialisation or integration into the global economy through state power and guidance is arguably not new. English mercantilism in the early days of English capitalism mirrored a similar state guided path to prosperity. ${ }^{7}$ Free trade only became the mantra of English capital and English economists once England, as part of the United Kingdom, became the dominant world power (Chang, 2007; Bairoch, 1993).

Some have argued that the newly industrialising countries (NIC) in Asia are examples of Listian Mercantilism (Brohman, 1996; Burmeister, 1990; Hoogvelt, 1990, White, 1988). As Brohman (1996, p.116)) explains it:

Rather than conforming to free trade and laissez-faire, NIC development strategies more closely resemble classical Listian mercantilism (Burmeister 1990; Hoogvelt 1990; White 1988). The nineteenth-century German economist Friedrich List (1916 [1844]) claimed that comparative advantage was a doctrine of the dominant; the dominated could expect to derive little advantage from it. Instead of allowing their markets to be dominated by established industrial powers through free-trade policies, List counseled late industrializers to protect strategic infant industries to strengthen their productive forces. An examination of early European industrialization reveals that most countries pursued Listian policies of economic nationalism with striking parallels to contemporary NIC strategies, including strong state intervention, infant industry protection, and ‘temporary dissociation’ from international competition during early industrialization.

The rise of Germany in the late $19^{\text {th }}$ Century and its emergence onto the global political and economic scene was only fully possible through the unification of the state in 1871 and both the importation of advanced technology into the country under the watchful eye of the state and state controlled growth behind trade barriers (Pierenkemper and Tilly, 2004). Indeed the establishment of the Zollverein, or Customs Union between some German speaking states in 1834 and its expansion over time was a necessary pre-condition for unity (Pierenkemper and Tilly, 2004). Only once the productive economic base had been built behind these barriers could Germany enter onto the world market but even then it was blocked by the already colonialised world and its trade blocs that prevented German access and further growth. The end result of this blocking process was World War I. The Asian Development Model has been more successful in Listian terms in allowing these countries to develop their productive forces behind trade and other barriers and then integrate into the 'free market' global economy. The Asian Development Model is one version of state capitalism (Bremmer, 2009).

\footnotetext{
${ }^{7}$ See, for example, Ian Austin, ‘Alexander Hamilton and Asian Capitalism’ Edith Cowan University

Research Online ECU Publications 2011, 3 and some of the authors he cites therein such as Jeffrey Sachs, The End of Poverty: How We Can Make It Happen In Our Lifetime (London \&New York: Penguin Books, 2005), Chuhei Sugiyama, Origins of Economic Thought in Modern Japan (1994, New York: Routledge Press) and Tetsuo Najita, ‘Japan’s Industrial Revolution in Historical Perspective’ in Masao Miyoshi and H.D. Harootunia (eds), Japan in the World (1994, London: Duke University Press) 13-30.
} 
Passant, McLaren, Silaen \& Wickramasinghe | Asian Development Model and Mining Reforms

\section{Modernisation}

This state capitalism approach appears to be a version of Modernisation Theory. As Peng (2009, pp. 37-38) puts it:

Luo Rongqu in his book, A New Thesis on Modernization (Xiandaihua xin lun), classifies the viewpoints of different scholars on the meaning of modernization into four categories:

1. Modernization is a historical process by which economically backward countries catch up with the world's advanced countries economically and technologically through technological revolution under the framework of specific international relations after the development of modern capitalism. ('The four modernizations' often mentioned in our country [China] fall into this category.)

2. Modernization in essence is industrialization. Put more accurately, it is the development process of industrialization by an economically backward country.

3. Modernization is the process and the generalized categorization of the sudden and abrupt changes of humankind since the revolution in the natural sciences.

4. Modernization is basically the changing process of psychological attitudes, social values, and lifestyles.

These four points of view are not contradictory to one another. On the contrary, they are related and complementary to each other.

In other words, 'modernisation' and leaving aside the Western bias of much of the theory and practice can mean among other things an historical process of 'catching up' to developed capitalist countries through rapid industrialisation (Peng, 2009). In the case of East Asian countries it has been, as it arguably was for the developed countries in their period of development, a symbiotic relationship between the state and local and international capital guiding and producing sometimes successfully, sometimes not, that industrialisation. It is 'the grand transformation from a traditional agricultural society to a modern industrial society...' (Peng, 2009). It is '.. the permeation of industrialism into the fields of economics, politics, culture, and ideology' (Lou, 2004).

As Cai (2012, p.63) puts it, in a long but informative quote:

From the perspective of modernization, Levy (1972, p. 6) distinguished three types of countries in the world:

“(1) The first comers, those cases where modernized patterns apparently developed slowly over a long period of time, and with no previous models before them. ... (2) A large number of cases, especially European ones, whose people were in rather close contact with the first comers during the development.... (3) Other latecomers, most of whose people were, or were kept, largely out of the contact with the modernized patterns of the first comers, and who came increasingly into contact with those patterns only after they were highly developed.

Accordingly, Luo Rongqu (2004), a leading Chinese scholar of modernization theory, put forward two types of modernization, namely 'first comer endogenous type' and 'latecomer exogenous type' The former type of modernization happened in the first comer 
countries, such as the UK, USA and France. These countries had no examples to follow and faced no external pressure when modernization was initiated. The modernization in these countries is a unique culture phenomenon (Kim, 2005, p. 3), and it started from shifts in internal value orientation. For instance, the French Revolution (1789) has become central to an analysis of the specificity of modernization in relation to the medieval world (Fehér, 1990). Among a variety of reasons triggering the Revolution, the shift in social theory and value orientation has been considered substantial; '[i]ts motor was ...the complicated cultural transformation of the country's possessing, administrative, and educated elites in the preceding century' (Higonnet, 1990, p.69).The shifts of cultural values gradually caused changes in social institutions. It was the new arrangements of social institutions that stimulated the technological innovation and economic development in Western Europe (North, 1981). The process of modernization is characterized as 'slow', 'gradual', 'stable' and 'harmonious' (Liu, 2007, p. 1).

The second type of modernization occurred as a national response to the demonstration, stimulation, challenge, exploitation, or even invasion by countries for which endogenous modernization has tremendously strengthened national wealth and power. China is a country which has been modernized mainly in the third wave in Levy's category, and also a typical case of exogenous modernization”.

Luo Rongqu offers a view of modernisation, specifically in justifying the contradiction that is called market socialism, in terms of what he calls 'one direction, many paths (Rongqu, 2009). Stripping aside the socialist rhetoric, and recognising Mao's China as a state capitalist regime and Deng Xiaoping's reforms as a move sideways from state to market capitalism (Shawki, 1997), the idea of many paths to capitalist development contains an appealing dialectical unity of opposites, or difference within the overarching reality of Lukacsian social totality (Lukacs, 2002). Not only that, Rongqu (2009) differentiates between the earlier period of western development happening in a world of early capitalism with few competitors and a world to expand into and divide up, and later capitalism with already developed and late developing countries and an already divided up world in which those late to the table have to fight for a seat at the feast of surplus value. These he calls 'first comer endogenous type' and 'latecomer exogenous type’ (Rongqu, 2009).

Indonesia is a late capitalist developer, one that, in the words of Luo Rongqu, is a case of the latecomer exogenous type, i.e. exogenous modernisation. It sees in the more industrially developed countries 'the image of its own future' (Marx, 1977). But this exogenous drive for development presents not just a set of natural laws of capitalist production 'working with iron necessity towards inevitable results' (Marx, 1977). There are a multiplicity of possible outcomes determined by the interaction of class and other forces within the national and global context of capitalism. There is a role for the state in managing those drivers within capitalism, to industrialise and hence transform the whole of the society from a peasant based society, for example to a modern capitalist society whose wealth is built on the back of an expanding working class, and if they are lucky, natural and other resources. In this instance, Indonesia is lucky. 
Passant, McLaren, Silaen \& Wickramasinghe | Asian Development Model and Mining Reforms

\section{E Marx, the Gatekeeper State and the Battering Ram}

Marx and Engels (2005) in the Communist Manifesto argued:

The bourgeoisie, by the rapid improvement of all instruments of production, by the immensely facilitated means of communication, draws all, even the most barbarian, nations into civilisation. The cheap prices of commodities are the heavy artillery with which it batters down all Chinese walls, with which it forces the barbarians' intensely obstinate hatred of foreigners to capitulate. It compels all nations, on pain of extinction, to adopt the bourgeois mode of production; it compels them to introduce what it calls civilisation into their midst, i.e., to become bourgeois themselves. In one word, it creates a world after its own image (Marx and Engel, 2005, pp. 45-46).

It is not just cheap prices which batter down all Chinese walls. The needs of a constantly expanding market for its product chase the bourgeoisie hither and thither across the globe. 'It must nestle everywhere, settle everywhere, and establish connections everywhere' (Marx and Engel, 2005). Marx and Engel (2005) were of course writing at a time when the state in the developed capitalist countries did not have the same power and strength or often extended role that it possesses today. They were also writing in a country, the United Kingdom, which had the most developed capitalist economy of the time and which was exporting or supporting its economic system through force of arms as well as markets.

Having noted that, the insights from Marx and Engels are relevant too for national economies wanting 'to catch up in the world market' (Smith, 2005). It is possible to see the State in developing countries as the gatekeeper of the national and global markets (Eckersley, 2006). The global bourgeoisie may not always need a battering ram to break into a country. The national State may invite it or sections of it in. On the other hand, it may reinforce the wall today against the battering ram to allow or create a future where the wall can be dismantled. Alternatively it may join with the external battering ram in destroying the wall. Sometimes it may resist the battering ram. Other times it may open the door and invite in the operators of the battering ram to enter. It may even allow newly created operators of battering rams within the country to leave and to ply their trade against other Chinese walls. The important point is that the State is the one who decides who and what comes in and out.

Even a free market is only free in a particular country because that State allows it to be so. Of course it goes without saying that the pressures of the local and global market, together with the institutions of neoliberalism like the austerity wavering International Monetary Fund (IMF) and the World Bank, plus the interests of dominant powers, can persuasively influence or even straightjacket a State in its choices. This means that the overarching goal of capitalist

development is imposed, perhaps freely, on welcoming nation States eager to join the club of developed or mid ranking nations who have pulled their peoples out of absolute poverty, while the methods and means to achieve that are or can be debated. 


\section{F The Prebisch-Singer Hypothesis}

On the question of methods and means, political acceptance of the Prebisch-Singer hypothesis may be one major driver for State intervention to encourage manufacturing rather than commodity production. The hypothesis argues that 'the net barter terms of trade between primary products such as raw materials and manufactured goods have been subject to a longrun downward trend' (Toye and Toye, 2003). This means in effect that developing countries which export raw commodities will fall behind those countries exporting manufactured goods (Cuddington, et al., 2007). This is true not just in terms of prices but also technological advance because there is 'a relatively slow rate of technical progress in the primary sector' (Cuddington, et al., 2007). The combination of a specialization in commodities, the slow rate of technical progress and the long term trend of lower commodity prices compared with manufactured goods would cause 'developing economies to lag behind the industrialized world' (Cuddington, et al., 2007). This leads to the conclusion that industrialisation is the only way to 'catch up' to the developed world (Cuddington, et al., 2007).

If correct, late comer countries should direct their development towards manufacturing rather than commodities. Of course resource rich countries will often try to mine and export their raw materials for the immediate gains but if Prebisch-Singer is correct then in the long term the production of commodities rather than manufactured goods will trap developing countries permanently behind the developed world. This point will be examined later in this paper when discussing the Indonesia Government's ban on unprocessed resources.

The Prebisch-Singer hypothesis raises two questions. ${ }^{8}$ First, is it correct? There has been much debate about the accuracy or otherwise of the hypothesis (Harvey et al, 2010). Harvey et al (2010) conclude, after examining four centuries of evidence, that for 11 major commodities the thesis is correct, that for 14 others there has been no decline nor increase and that overall 'in the very long run, there is simply no statistical evidence that relative commodity prices have ever trended upward' (Harvey, et al., 2010).

The second question is what do politicians think? If they believe the hypothesis is correct, or has validity, they may, depending on their particular national circumstances, orient their economies towards industrialisation rather than raw commodities. In the case of a resource rich and dependent country like Indonesia the ban on the export of unprocessed minerals can be seen as an attempt to mandate the processing of commodities for the purposes of industrialisation (Bland, 2014).

Before examining the mining changes in Indonesia, it is important to summarise the discussion so far. Government intervention occurs in various ways to build manufacturing industry, often through import substitution to start with, followed by an export orientation once those industries have become globally efficient. In essence the Asian Development

\footnotetext{
${ }^{8}$ It does raise a third. Is Trotsky’s theory of uneven and combined development a better theoretical basis for understanding global development? In essence this theory involves 'the combination of the capitalist mode of production with pre-existing modes’ and their complex interactions (Burawoy,1985, p.99).
} 
Model is about 'beneficial strategic state interventions' for late developing capitalist countries starting out on the sidelines of world capitalism or as one of its reserves.

This can be seen in relation to the ongoing mining reforms in Indonesia and the need to both re-distribute the benefits to, in the main, sections of the Indonesian elite rather than multinationals through the divestment requirement and the majority Indonesian ownership requirement and at the same time mandating further industrialisation through the ban on the export of unprocessed minerals.

\section{Mining Reforms in Indonesia}

Indonesia is a resource rich country. It '.. has huge mining and mineral reserves especially coal, copper, tin, nickel, iron and bauxite' (Extractive Industries Transparency Initiative, 2014, p.15). Mining is an important part of the Indonesia economy, accounting for 'around 12 percent of Indonesia's GDP, and 20 percent of all foreign direct investment flows' (Business Monitor International, 2014, p.8). In 2005, as a result of the boom in the price of natural resources, commodities, at 65 percent of total exports, exceeded manufacturing as the largest export sector (World Bank, 2014). In recent times, and recognising the downturn in commodity prices since 2011, according to PwC (2014) mining itself totals about 20 percent of total exports, and contributes about 5-6 percent to GDP. This has helped contribute to a decline in poverty from 24 percent of the population in 1999, the year after the dictatorship fell, to 12 percent in 2012 under the democratic system of government in place (World Bank, 2014).

The Indonesian state sees itself as having a key role to play in the on-going development of the country. Thus it has developed the National Long-Term Development Plan (RPJPN 2005-2025). Its vision and mission 'is to establish a country that is developed and self-reliant, just and democratic, and peaceful and united'. Indonesia-Investment goes on to say that one of the main objects of the plan is (Indonesia-Investment ):

The establishment of a solid structure in which the agricultural economy (in the broad sense) and mining form the basis of an economy that produces products in both an efficient and modern manner, in which the manufacturing industry contains global competitiveness and becomes the motor of the economy, and services become the glue of economic resilience.

One consequence of the boom in resource prices in the first decade of this century has been that 'high commodity prices tilted investment incentives in favour of the resource sector and non-tradable sectors (e.g., the real estate sector) against manufacturing and other tradable sectors' (World Bank, 2014). While this might be an indicator of Dutch Disease , ${ }^{9}$ the IMF and World Bank both think that for a number of reasons, including exchange rates still reflecting economic fundamentals, and the existence of surplus labour in Java, where most

\footnotetext{
${ }^{9}$ Dutch disease is the term used to describe the economic consequences of oil development in the North Sea within the territory of the Netherlands in the 1960's where as a result of the new found wealth from oil the currency of the Netherlands increased making non-oil sector exports expensive and detrimental to the rest of the economy.
} 
manufacturing industries are located and keeping downward pressure on manufacturing wages, Indonesia has not been infected. However, this over-investment and over-reliance on resources, coupled with a downturn in commodity prices since 2011, could slow down the Indonesian economy. If the Prebisch-Singer hypothesis is correct it could also in the long term see Indonesia in a resource trap and unable to catch up to developed nations because of a lack of or under-investment in manufacturing.

\section{A The Law on Mineral and Coal Mining No 4/2009}

One State response, driven by the desire to 'maximise the benefits of the coal and minerals sectors for Indonesia'(PwC, 2014) has been the Law on Mineral and Coal Mining No 4/2009 (the 'Mining Law') which the Indonesian Parliament passed on 12 January 2009 (PwC, 2014). This new law replaced the old, almost open slather, regulatory regime the Suharto government introduced in 1967. Key features include a ban on exports of unprocessed commodities, long-term foreign divestment to enable 51 percent Indonesian ownership, planning and environmental regulation including the right of provincial and local governments as well as the national to issue mining licences in some cases, and local market supply requirements.

Baird and Wihardja (2010) describe the export ban as introducing 'long discredited policies intended to 'increase value added' by requiring the domestic processing of minerals' (Baird and Wihardja, 2010). The ban mainly affects 'copper ore, nickel ore (of which Indonesia is responsible for half of global production), and bauxite' (Howes and Davies, 2014). Export of the latter two is banned altogether (Howes and Davies, 2014). Copper concentrate can be exported until 2017, but the exporters have to pay an export tax of 20 percent, a tax that will increase over time (Howes and Davies, 2014). In the past these three minerals have not been processed in Indonesia (Howes and Davies, 2014). As a consequence exports of all three have stopped (Howes and Davies, 2014).

Eve Warburton (2014) puts it this way in describing the proffered reasons for the Mining Law Reforms:

The government argues that if Indonesians are to prosper, the country should no longer export raw commodities to richer countries via multinational companies. Officials have stated that if Indonesia is to move beyond the middle-income bracket it must begin adding value domestically and building its domestic mining industry. State officials also defend nationalist policies as a necessary step towards more just systems of rent distribution. Former Director General for Coal and Mineral Resources Thamrin Sihite, for example, said the government wants 'the benefits of our country's resources to reach more Indonesians.' President Yudhoyono himself claimed that, 'many multinational corporations take too much and do not leave behind enough for the people of those countries...we want to have a fair share too’. 
Others call it resource nationalism driven by political opportunism, not concerns about developing the nation and benefiting the population (Warburton, 2014).

However, both views may be correct. The overthrow of the Suharto government ushered in a new democratic Indonesia (Webber, 2006). The demands of the people have been for the benefits of the economy, including mining, to flow to them and not just to big business such as the dominant players like American based companies Freeport McMoRan and Newmont, the two companies which dominate the natural resources sector. The demands of the people or significant numbers of them for better lives have to be both echoed by at least some elected politicians, and over time, met. If they are not met it is possible no amount of populist propaganda alone will save the populist politicians.

\section{B A Weak State Meeting its Match?}

Webber (2006) goes so far as to suggest this gap between words and real benefits is already an issue when he describes one of the main problems with Indonesian democracy being the weakness of the State and its lack of capacity 'to implement and deliver policies orientated towards universalistic ends. He identifies the small government revenue take, the failure of spending to reach its targets and corruption as the main contributors to this result (Webber, 2006).

The irony of the Mining Law is that in appearing to be strong the Indonesian State may well be showing its real weakness and its inability to force reluctant and powerful sectors of capital to do its bidding. The question of whether the battering ram that the Indonesian state has taken to both foreign mining capital, in terms of the divestment proposal and ban on exports of unprocessed ores and onshore smelter requirement, and local mining capital in terms of the ban and smelter requirements, will in fact redistribute wealth to poorer Indonesians is yet to be fully answered. However the cessation of exports of copper or, nickel ore and bauxite as a result of the export ban (PwC. 2014) suggests that capital may be responding with its own battering ram. Mining companies have also retrenched large number of workers. For example, Newmont Mining has shut down its Indonesian operations over the export ban, the high and increasing royalties on allowed exports until 2017 and in-country smelting (MacLean. 2014). Churchill Mining is also in dispute with the Government, while Freeport-McMoRan has decided to negotiate, rather than fight the government, over the Mining Law and its consequences for them (MacLean. 2014).

While unemployment rose from 5.7 percent in the first quarter of 2014 to 5.94 percent in the third quarter, the employment trend in the mining industry appears, on first quarter figures for 2014 from Statistics Indonesia, to have been in the other direction. In 2012 the number of people employed in mining in Indonesia was around 1.6 million (Badan Pusat Statistik, 2004). In 2013 this fell to 1.46 million in the third quarter, yet rose in the first quarter 2014 to over 1.6 million. While one quarter is not enough to establish a trend, one tentative conclusion, until later figures are available, is that mining capital anticipated the impacts of the Mining Law reforms being implemented in 2014 by cutting back on staff in 2013, and 
then recruiting more staff after the laws came into effect and their impact was less disastrous than anticipated. However it is necessary to keep in mind that this is very tentative, and also takes no account of other factors which may have influenced employment in the industry, such as rising or falling commodity prices during the years in question. It is also contradicted by, for example, statements by Erry Sofyan, Secretary-General of the Indonesian Bauxite and Iron Ore Entrepreneurs Association, who has said that of five new smelters being built three are on hold because of, among other things, a court challenge to the constitutionality of the Mining Law and that 51 bauxite mining companies have stopped operations since January 2014, with 40,000 workers being laid off. Certainly the ban has had 'a significant impact on Indonesia's export revenues (PwC, 2014).

\section{Foreign Direct Investment}

However, the Foreign Direct Investment (FDI) figures tell a more complex story. As mentioned earlier, mining accounts for 20 percent of all FDI into Indonesia. In the first quarter of 2014 FDI growth slowed to 9.8 percent in part because of political uncertainty in the run up to legislative and presidential elections (Sambijantoro, 2014) and in part because of the uncertainty about the impact of the Mining Law. However in the second quarter of 2014, despite the fact that the political uncertainty continued, since the Presidential elections were not until after that quarter ended, on 9 July, FDI increased by 16.9 percent year on year, boosted by FDI in smelters (Sambijantoro, 2014). The outlook for investment, and in particular FDI, is bright (Indonesia Investment Coordinating Board, 2014).

Whatever the best political descriptor might be of the Mining Law reforms, they need regulations to implement them. PwC (2014) describe those to date that have been implemented as reflecting 'the theme of ensuring the benefits of mining are retained and reinvested in Indonesia'. The implementing regulations include divestment arrangements over ten years from the time production begins to ensure 51 percent Indonesian ownership, the export ban on unprocessed minerals and a requirement for in-country processing, minimum domestic market requirements for coal and benchmarks to set minimum prices for coal and mineral exports (PwC, 2014).

\section{$D \quad$ Uncertainty}

However the history of both the Mining Law and the regulations implementing them has been of uncertainty. Certainly the constitutional challenge is one reason for this. Another is the toing and froing by the government of Susilo Bambang Yudhoyono on the Mining Law. For example the ban on exporting unprocessed commodities other than nickel, copper and bauxite was relaxed for companies who agreed to build smelters by 2017 and pay increasing royalties of up to $60 \%$ by the end of that period. The new President, Joko Widodo, sworn in on 20 October for a 5 year term, was prepared to negotiate over the detail of the Mining Law (MacLean, 2014). 
While the Mining Law is in place, the uncertainty about its constitutionality, the previous government's lack of clear advice on implementation, and the Presidents preparedness to negotiate, create a situation of uncertainty for investors and mining companies. Couple that with the deleterious effects the various Mining Law reforms are having on mining companies, revenue and jobs it may be that the Indonesian State has gone too far with its Mining Law. This is stated as a realistic observation of the current situation in Indonesia. However, it is not a criticism of the intent of the Mining Laws.

There is a famous saying: you can peel an onion layer by layer, but you cannot skin a tiger claw by claw. Mining companies are not onions: they are tigers. That means any battering ram the Indonesian State takes to them has to do the job properly. In the long run, in a global economy desperate for minerals and energy, other resource rich countries may be able to fill the gap left by a capital strike or slowdown in Indonesia. At the moment that global demand is lessening. As Behre Dolbear (2014) put it: 'Moderating mineral consumption on the back of declining government stimulus, in many major economies, led to downward trading ranges for most minerals'. However, for them, long term, the fundamentals remain strong (Dolbear, 2014).

What is important right now is the impact the Mining Law have on Indonesia's economy. Although it is early days, it appears to have provoked both a move to industrialisation, based on the investment figures, and de-industrialisation and a decline in resource production base on jobs, revenue and export figures. This industrialisation and de-industrialisation dichotomy may be explained by the fact that it is multinationals who are best positioned to build smelters. The ban on exports may be driving out smaller Indonesian miners from the industry. If that dichotomy continues then Indonesian capital and the Indonesian people may force the State to change its approach. The Asian Development Model is not a panacea.

\section{Conclusion}

There is an Asian Development Model, and the implementation of the Mining Laws in Indonesia is an example of the State using its power to influence the direction of mining in its own country. It is doing this to ensure that greater industrialisation in Indonesia occurs and that the benefits of mining flow more to the Indonesian people. The particular reforms themselves, however, may not meet their stated goals, but rather produce an industrialisation by foreign capital at the expense of local capital, which is the opposite result intended by the gradual move to majority Indonesian ownership of foreign mining companies. This may highlight the ambiguously weak nature of the Indonesian State in imposing its will on foreign and local capital. The State as a battering ram is perhaps being battered, not by foreign capital but by local capital. Only time will tell. 


\section{References}

Amsden, Alice (1994), "Why isn’t the whole world experimenting with the East Asian model to develop?: review of the East Asian miracle”, World Development, 22 (4), pp. 627628. http://dx.doi.org/10.1016/0305-750X(94)90117-1

Ariff, Mohamed and Ahmed, M. Khalid (2000), Liberalization, Growth and the Asian Financial Crisis: Lessons for Developing and Transitional Economies in Asia, Edward Elgar Publishing Ltd, Cheltenham, p. 110.

Ashton, David, Francis Green, Johnny Sung and Donna James (2002), “The Evolution of Education and Training Strategies in Singapore, Taiwan and S. Korea: a development model of skill formation”, Journal of Education and Work, 15(1), pp. 5-6. http://dx.doi.org/10.1080/13639080120106695

Austin, Ian (2011), “Alexander Hamilton and Asian Capitalism” Research Online ECU Publications, Edith Cowan University, p.3

Badan Pusat Statistik, "Population 15 Years of Age and Over Who Worked by Main Industry, 2004-2014”

<http://www.bps.go.id/eng/tab_sub/view.php?kat=1\&tabel=1\&daftar=1\&id_subyek=06 \&notab=2>. Viewed 15 November 2014.

Baek, Seung-Wook (2005), “Does China Follow "the East Asian Development Model?”, Journal of Contemporary Asia, 35(4), p. 485. http://dx.doi.org/10.1080/00472330580000281

Baird, Mark and Maria Monica Wihardja (2010), “Survey of recent developments” Bulletin of

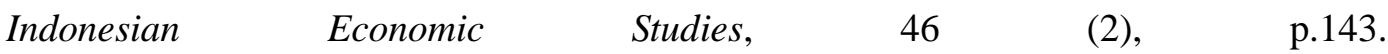
http://dx.doi.org/10.1080/00074918.2010.486107

Bairoch, Paul (1993), Economics and World History-Myths and Paradoxes, University of Chicago Press, p. 43.

Bland, Ben (2014), “Indonesia slaps ban on mineral exports” Financial Times 12 January $2014<$ http://www.ft.com/intl/cms/s/0/d643e66e-7b71-11e3-a2da00144feabdc0.html\#axzz3JDCSu6ni>.

Bremmer, Ian (2009), “State Capitalism Comes of Age: The End of the Free Market?", Foreign Affairs, 88 (3), pp. 40, 42 and 46.

Brohman, John (1996), "Postwar Development in the Asian NICs: Does the Neoliberal Model Fit Reality?”, Economic Geography, 72(2), pp. 107-116. http://dx.doi.org/10.2307/144262

Burawoy, Michael (1985), The Politics of Production: Factory Regimes under Capitalism and Socialism, Routledge, p. 99.

Burmeister, Larry L, (1990), “ State industrialization and agricultural policy in Korea”, Development and Change, 21, pp. 197-223. http://dx.doi.org/10.1111/j.14677660.1990.tb00375.x

Business Monitor International, Indonesia Mining Report Q4 2014, Business Monitor Internal, p. 8. 
Passant, McLaren, Silaen \& Wickramasinghe | Asian Development Model and Mining Reforms

Cai, Yuzhuo (2012), “Traditional Reform Philosophy and Challenges of Higher Education Reforms in China”, Special Issue International Journal of Humanities and Social Science, 2 (6), pp. 60-63.

Chang, Ha-Joon (2007), Bad Samaritans: The Myth of Free Trade and the Secret history of Capitalism, Bloomsbury Press, pp. 8-31.

Channel News Asia (2014), "Singapore wants to advance relationship with Indonesia: PM Lee to President Widodo" Channel News Asia 20 October 2014 <http://www.channelnewsasia.com/news/singapore/singapore-wants-to/1426062.html>.

Cuddington, John T, Rodney Ludema, and Shamila A Jayasuriya (2007). "Prebisch-Singer Redux" in Daniel Lederman and William F. Maloney (eds) Natural Resources: Neither Curse nor Destiny, Stanford University Press and World Bank, Washington), p. 103.

Dolbear, Behre (2014), “Ranking of Countries for Mining Investment: Where Not to Invest”, p. <http://www.dolbear.com/_literature_209687/2014_Ranking_of_Countries_for_Mining _Investment>. Viewed 18 November 2014.

Eckersley, Robyn (2006), “The State as Gatekeeper: A Reply”, Politics and Ethics Review, 2(2), pp. 127-137. http://dx.doi.org/10.3366/per.2006.2.2.127

Extractive Industries Transparency Initiative, Indonesia, EITI Reconciler's Report 2010 and 2011 - Mining Industry (Jakarta 2014) 15.

Freeman, Nick and Denis Hew (2002), "Rethinking the East Asian development model”, ASEAN Economic Bulletin, 19 (1), p.1. http://dx.doi.org/10.1355/AE19-1A

Gandataruna, Kosim and Kirsty Haymon (2011), “A Dream Denied? Mining Legislation and the Constitution in Indonesia” Bulletin of Indonesian Economic Studies, 47 (2), pp. 221, 229. http://dx.doi.org/10.1080/00074918.2011.585951

Guo, Yvonne (2014), “Singapore and Indonesia: An Uneasy Coexistence?” The Diplomat, 15 February $2014<$ http://thediplomat.com/2014/02/singapore-and-indonesia-an-uneasycoexistence/>.

Hall, Rodney Bruce (2003), “The Discursive Demolition of the Asian Development Model” International Studies Quarterly, 47, pp. 71-73 http://dx.doi.org/10.1111/1468-2478.4701004

Harvey, David I., Neil M. Kellard, Jakob B. Madsen and Mark E. Wohar (2010), "The Prebisch-Singer Hypothesis: Four Centuries of Evidence”, The Review of Economics and Statistics, 92(2), pp. 367-375. http://dx.doi.org/10.1162/rest.2010.12184

Hill, Hal (2014), “Is There a Southeast Asian Development Model?”, Malaysian Journal of Economic Studies (Special Edition),51, p. 89.

Hoogvelt, Ankie, (1990), “Extended review, rethinking development theory”, The Sociological Review, $38 \quad$ (2), pp. 352-361. http://dx.doi.org/10.1111/j.1467954X.1990.tb00916.x

Howes, Stephen and Robin Davies (2014), “Survey of Recent Developments” Bulletin of 
AABFJ | Volume 9, no. 2, 2015

$\begin{array}{lllll}\text { Indonesian } \quad \text { Economic } & \text { Studies, } & 50 & \text { (2), } & \text { pp. }\end{array}$ http://dx.doi.org/10.1080/00074918.2014.938403

IMF (1997), “World Economic Outlook: Interim Assessment”, World Bank, Washington DC, December.

Indonesia Investment Coordinating Board, "Investment Realization in Quarter II of 2014 Hit Another Highest Record”, <http://www5.bkpm.go.id/contents/news_detail/191401/press-release-investmentrealization-in-quarter-ii-of-2014-hit-another-highest-record\#.VG7Hk3IcSUk>. Viewed 21 November 2014.

Indonesia-Investment (2014), “National Long-Term Development Plan (RPJPN 2005-2025)”, $<$ http://www.indonesia-investments.com/projects/government-developmentplans/national-long-term-development-plan-rpjpn-2005-2025/item308>, viewed 11 November 2014.

Indonesia-Investments (2014), “New Mining Law of Indonesia: Construction of many Smelters Delayed” Indonesia-Investments 19 June $2014<$ http://www.indonesiainvestments.com/news/todays-headlines/new-mining-law-of-indonesia-construction-ofsmelters-delayed/item2124> viewed 16 November 2014.

Lukács, Georg (2002), History and Class Consciousness, MIT Press, Cambridge.

MacLean, Dana (2014), “Hopes and challenges” Asian Legal Business, 1 August 2014 $<$ http://www.legalbusinessonline.com/features/hopes-and-challenges/66609> viewed 15 November 2015.

Marx, Karl (1977), "Preface to the First German Edition in Karl Marx”, Capital, Volume 1, Progress Publishers, Moscow.

Marx, Karl and Frederick Engels (2005), The Communist Manifesto: A Road Map to History's Most Important Political Document, edited by Phil Gasper, Haymarket Books, Chicago.

McKay, John (2010), “The Asian 'Miracle' After the Global Financial Crisis: Some Lessons for Africa” (Discussion Paper 2010/07 The Brenthurst Foundation, Marshalltown) $<$ http://thebrenthurstfoundation.co.za/Files/Brenthurst_Commisioned_Reports/BD1007 -Asian-miracle.pdf>.

Moletti, Umberto (1982), Marx and the Third World, Macmillan Press, London.

Najita, Tetsuo (1994), “Japan’s Industrial Revolution in Historical Perspective” in Masao Miyoshi and H.D. Harootunia (eds), Japan in the World, London: Duke University Press, pp. 13-30.

Peng, Yuan (2009), "Modernization Theory-From Historical Misunderstanding to Realistic Development: A Review of A New Thesis on Modernization”, Chinese Studies in History, 43(1), pp. 37-38. http://dx.doi.org/10.2753/CSH0009-4633430104

Perkins, Dwight (2013), East Asian Development: Foundations and Strategies, Cambridge: 
Passant, McLaren, Silaen \& Wickramasinghe | Asian Development Model and Mining Reforms

Harvard University Press. http://dx.doi.org/10.4159/harvard.9780674726130

Pierenkemper, Toni and Richard H. Tilly (2004), The German Economy During the Nineteenth Century, Berghahn Books.

Pomeranz, Kenneth (2001), "Is there an east Asian development path? Longterm comparisons, constraints, and continuities”, Journal of the Economic and Social History of the Orient, 44(3), p.322. http://dx.doi.org/10.1163/156852001320123119

PwC (2013), “Mining in Indonesia”, Jakarta.

Rongqu, Lou (2004), Xiandaihua xin lun (A new theory of modernisation), Shangwu Publishing House, Beijing.

Rongqu, Luo (2009), "New Perspectives on Historical Development and the Course of Modernization in East Asia" Chinese Studies in History, 43(1), pp. 17-21. http://dx.doi.org/10.2753/CSH0009-4633430102

Sachs, Jeffrey (2005), The End of Poverty: How We Can Make It Happen In Our Lifetime, Penguin, London.

Sambijantoro, Satria (2014), “Mining Law boosts foreign investment”, The Jakarta Post, 25 July 2014. <http://www.thejakartapost.com/news/2014/07/25/mining-law-boostsforeign-investment.html>. Viewed 21 November 2014.

Shawki, Ahmed (1997), “China: From Mao to Deng”, International Socialist Review, Summer, volume 1.

Singh, Ajit (2002), “Asian Capitalism and the Financial Crisis”, in John Eatwell and Lance Taylor, (eds) International Capital Markets: Systems in Transition, Oxford University Press.

Smith, Tony (2005), Globalisation: A Systemic Marxist Account, Haymarket Books, Chicago.

Sugiyama, Chuhei (1994), Origins of Economic Thought in Modern Japan, Routledge Press, New York

The World Bank, "Indonesia Overview", The World Bank $<$ http://www.worldbank.org/en/country/indonesia/overview>.

The World Bank, Indonesia Overview, The World Bank <http://www.worldbank.org/en/country/indonesia/overview>.

Toye, John and Richard Toye (2003), “The Origins and Interpretation of the Prebisch-Singer Thesis” History of Political Economy, 35:3, pp. 437.

Wade Robert and Frank Veneroso (1998), “The Asian Crisis: The High Debt Model Versus the Wall Street-Treasury-IMF Complex”, New Left Review, 228, March-April, pp. 3-24.

Wade, Robert (2004) 'The Reprinting of Governing The Market: A Dinner Table Conversation', Issues \& Studies, 40 (1), pp. 103-134.

Warburton, Eve (2014), "In Whose Interest? Debating resource nationalism in Indonesia” Kyoto Review of Southeast Asia, Marc, p. $15<\mathrm{http} / /$ kyotoreview.org/yav/in-whose- 
AABFJ | Volume 9, no. 2, 2015

interest-debating-resource-nationalism-in-indonesia/>, viewed 12 November 2014.

Webber, Douglas (2006), “A consolidated patrimonial democracy? Democratization in postSuharto Indonesia” Democratization, 13(3), pp. 396-408. http://dx.doi.org/10.1080/13510340600579284

White, Gordon (1988), Developmental States in East Asia, St Martin’s, New York.

World Bank (1993), “The East Asian Miracle: Economic Growth and Public Policy”, A World Bank Policy Research Report, Oxford University Press, New York.

World Bank, Indonesia (2014), “Avoiding the Trap”, Jakarta, p. 3.

Yeo, Caroline and Wong, Siang Yeung (2010), "Selective Intervention and Economic ReEngineering: Lessons from Singapore’s Parks in Indonesia and India”, Journal of Asian Business Studies, 20(2), p. 13. 